\title{
Effect of Bio-Organics and Mineral Nutrients on Yield, Quality and Economics of Sprouting Broccoli (Brassica oleracea var. italica)
}

\author{
Sunil Choudhary ${ }^{1 *}$ and Ravinder Paliwal ${ }^{2}$ \\ ${ }^{1}$ Department of horticulture, Sri Karan Narendra Agriculture University, Jobner, Rajasthan, India \\ ${ }^{2}$ Department of Horticulture, RARI, Durgapura (SKNAU, Jobner), Jaipur, India \\ *Corresponding author
}

\section{A B S T R A C T}

\begin{tabular}{|l|}
\hline K e y w or d s \\
Sprouting broccoli, \\
Bio-organics, Mineral \\
nutrients, \\
Azospirillum, PSB, \\
FYM, Vermicompost, \\
Yield, Quality. \\
\hline Article Info \\
\hline Accepted: \\
07 October 2017 \\
Available Online: \\
10 December 2017 \\
\hline
\end{tabular}

The present investigation was carried out during rabi season 2013-14 at the horticulture farm, S.K.N. Collage of agriculture, Jobner (Rajasthan) to study the effect of bio-organics and mineral nutrients on performance of sprouting broccoli. The experiment consisted of four levels of bio-organics (control, vermicompost @ $5 \mathrm{t} / \mathrm{ha}$, vermicompost @ $2.5 \mathrm{t} / \mathrm{ha}+$ FYM @ 5 t/ha and vermicompost @ $2.5 \mathrm{t} / \mathrm{ha}+\mathrm{FYM} @ 5 \mathrm{t} / \mathrm{ha}+$ Azospirillum + PSB) and four levels of mineral nutrients (Control, Sulphur @ $40 \mathrm{~kg} / \mathrm{ha}$, Sulphur @ $40 \mathrm{~kg} / \mathrm{ha}+$ Zinc @ $5 \mathrm{~kg} / \mathrm{ha}$ and Sulphur @ $40 \mathrm{~kg} / \mathrm{ha}+$ Zinc @ $5 \mathrm{~kg} / \mathrm{ha}+$ Boron @ $1.5 \mathrm{~kg} / \mathrm{ha}$ ) in factorial Randomized Block Design with three replications. The application of vermicompost @ 2.5 t/ha + FYM @ 5 t/ha + Azospirillum + PSB along with sulphur @ 40 kg/ha + zinc @ 5 $\mathrm{kg} / \mathrm{ha}+$ boron@1.5 kg/ha proved to be the best treatment combination in terms of average weight of central head, average weight of secondary heads, diameter of head, total head yield, crude protin content, vitamin-C content in head and net return of sprouting broccoli. The combination produced $337.28 \mathrm{q} / \mathrm{ha}$ head yield along with net return of Rs.609982 per ha.

\section{Introduction}

Broccoli (Brassica olerasia var. italica) is one of the important cool season vegetable of Brassicacae family. Broccoli is an Italian word originated from Latin 'Brachium' meaning an arm or branch (Thamburaj and Singh, 2013). It is a high value exotic vegetable and cultivated for its tender flowering head and the secondary heads $i . e$. spears which develop in the axils of leaves and may contribute up to 50 per cent of the total yield. Generally it can be classified into three distinct group viz., white purple and green, out of which green type is highly nutritious (Yoldas et al., 2008). Broccoli is rich source of vitamins, minerals and essential amino acids, also contains the compound namely, glucoraphanin, which can be processed into an anti-cancer compound sulphoraphane (Shiwani et al., 2016). It was a rare cole crop in India but now it is gaining popularity in metropolitan cities, reputed hotels and restaurants (Maurya, 2008). Indiscriminate use of fertilizers and other agrochemicals have resulted in the depletion of beneficial micro-organism from the soil and have caused infertile and unproductive soil. Therefore integrated nutrient management is an important demand of present era. The main aim of integrated nutrient management is to cultivate a land in 
such a way that the soil should remain sustainable with maximum quality production of crop (Mishra et al., 2014). FYM and vermicompost are slow releasing organic manures which have most of the macro as well as micro nutrients in chelated form and fulfill the nutrient requirement of plants as longer period. Organic manures also help in reducing $\mathrm{C}: \mathrm{N}$ ratio, increasing humic acid content and provide nutrient in the readily available form to the plants such as nitrate, exchangeable phosphorus, soluble potassium, calcium and magnesium (Talashilkar et al., 1999). In addition organic manure improves soil physical properties like structure, water holding capacity. Bio-fertilizers play an important role in increasing availability of nutrients and productivity in sustainable manner. Azospirillum is free living bacteria which may add to non-legume crop under favourable condition and also secrets some growth promoting substances. Inoculation of seeds with PSB culture increase nodulation, crop growth, nitrogenase activity, nutrient uptake and crop yield. Thus bio-fertilizers play multifaceted role by not only enriching the soil micro-organism but also as nutrients, stabilizers, hormones and insulators (Mohapatra et al., 2013). The advantages of integrated nutrients management generally superior over use of each component separately. Integration of chemical fertilizers with organic manures and bio-fertilizers had maintained long term fertility and sustains higher productivity. Considering the above factors, the present experiment was undertaken to determine the best bio-organic and mineral nutrient fertilizers combination for maximum yield and net profit in broccoli.

\section{Materials and Methods}

Present field experiment was conducted at Experimental Farm, Department of Horticulture, S.K.N. College of Agriculture, Jobner during rabi season 2013-14. The treatment combinations comprised four levels of bio-organics (control, vermicompost @ 5 t/ha, vermicompost@2.5t/ha+FYM@5 t/ha and vermicompost@2.5 t/ha +FYM @ $5 \mathrm{t} / \mathrm{ha}+$ Azospirillum + PSB inoculation) and four levels of mineral nutrients (Control, Sulphur@40 kg/ha, Sulphur @ 40 kg/ha + Zinc@ 5 kg/ha and Sulphur @ 40 kg/ha + Zinc@ @ kg/ha + Boron @ $1.5 \mathrm{~kg} / \mathrm{ha}$ ), thereby, made 16 treatment combinations, which were replicated thrice in the Factorial Randomized Block Design. The seeds were sown on $8^{\text {th }}$ September, 2013 in shallow furrows $5-6 \mathrm{~cm}$ apart by dropping the seeds at 1-2 cm depth. A thin layer of powdered leaf mould was applied to cover the seeds. Regular watering, hoeing, weeding, plant protection measures etc. were done time to time. The seedlings were ready for transplanting within six weeks. Different organic manures viz. farm yard manure (FYM) and vermicompost were applied before transplanting as per the treatment and mixed thoroughly in the soil. The weighed quantity of gypsum, zinc sulphate and borax were mixed with soil and incorporated uniformly in each plot. Six weeks old seedlings brought out from nursery bed and treated by dipping of roots into the prepared culture of bio-fertilizer as per treatments for 30 minutes and then transplanted into plots of $1.8 \mathrm{~m} \mathrm{x} 1.8 \mathrm{~m}$ at spacing of $45 \times 45 \mathrm{~cm}$. The treatments were: $\mathrm{B}_{0}$-control, $\mathrm{B}_{1}$ Vermincompost @ 5 t/ha, B B $_{2}$ Vermicompost @ 2.5 t/ha + FYM @ 5 t/ha, B $3^{-}$ Vermicompost @ 2.5 t/ha +FYM @ 5 t/ha + Azosprillum + PSB, $\mathrm{F}_{0}$-control, $\mathrm{F}_{1}$-Sulphur @ 40kg/ha, F 2 -Sulphur@40 kg/ha + Zinc @ 5 kg/ha, F 3 -Sulphur @40 kg/ha + Zinc @ 5 $\mathrm{kg} / \mathrm{ha}+$ Boron@1.5 kg/ha The different yield and quality observations were recorded from five randomly selected plants from each plot. The other cultural operations were done as per recommendation and crop requirement. The observations like diameter of curd $(\mathrm{cm})$, weight of curd $(\mathrm{g})$, curd yield per plot $(\mathrm{kg})$ 
and curd yield (tonnes/ha) were recorded. Economics of the experiment was worked out on the basis of prevailing market prices of inputs and outputs. The data of the trial obtained were subjected to statistical analysis and the results were documented, analysed and presented in tabular form.

\section{Results and Discussion}

\section{Effect of bio-organics}

The presented data in table 1 is concerning with the quality attributes of broccoli as affected by different bio-organics and mineral nutrients either alone or in combinations. Maximum crude protein content $(2.30 \%)$ in head was recorded with treatment $B_{3}$ (Vermicompost $2.5 \mathrm{t} \mathrm{ha}^{-1}+$ FYM $5 \mathrm{t} \mathrm{ha}^{-1}+$ Azosprillum + PSB) which was statistically significant than all other treatments tried in the experiments and followed by $2.14 \%$ with treatment $\mathrm{B}_{2}$ (Vermicompost @ 2.5 t/ha + FYM@ 5 t/ha).

The increase in protein content might be due to better availability of desired and required quantity of $\mathrm{N}$ in root zone of the crop resulting from its solublization called by organic acid and produced from the decaying of the organic matter. Since protein content is function of $\mathrm{N}$ content in seeds.

The increased uptake of nutrients by broccoli roots may also be due to the increased availability of nitrogen resulting from the atmospheric $\mathrm{N}$ - fixation by bio-fertilizers and enhanced synthesis of protein facilities by the supply of growth principals like enzymes and growth regulators received from the manures and bio-fertilizers (Sable and Bhamare, 2007). The beneficial effects of organic matter on protein content are also reported due to increased $\mathrm{N}$ content in seeds by Kumar et al., (2012). The increase in protein may also be due to the increased activity of nitrate reductase enzymes which might be helped in synthesis of amino acids and protein (Choudhary et al., 2012).

Highest vitamin-C content $(85.17 \mathrm{mg} / 100 \mathrm{~g})$ was recorded with treatment $\mathrm{B}_{3}$ (Vermicompost $2.5 \mathrm{t} \mathrm{ha}^{-1}+$ FYM $5 \mathrm{t} \mathrm{ha}^{-1}+$ Azosprillum + PSB) followed by 77.37 $\mathrm{mg} / 100 \mathrm{~g}$ with treatment $\mathrm{B}_{2}$ (Vermicompost @2.5 t/ha +FYM @ 5 t/ha). The increase in Vitamin-C content in broccoli might be due to increase in microbial activity of soil which might have added growth regulators, vitamins and hormones to the plants.

There is a general observation that organically managed crop have usually higher vitamin $\mathrm{C}$ than the conventional fertilized crop because when a plant is exposed with more nitrogen, it increases protein production and reduces carbohydrates synthesis. Since vitamin C is synthesized from carbohydrates, its levels are also reduced. In case of organically managed soil, plants are generally exposed with comparatively lower amount of nitrogen and several plant nutrients are released slowly over time. Therefore, organic crop would be expected to maintain higher vitamin ' $C$ ' as reported by Bahadur et al., (2003) in broccoli.

Maximum nitrogen content $(0.368 \%)$, zinc content (43.03 ppm) and boron content $(0.0049 \%)$ in head were recorded with treatment $\mathrm{B}_{3}$ (vermicompost $2.5 \mathrm{tha}^{-1}+\mathrm{FYM}$ $5 \mathrm{t} \mathrm{ha}^{-1}+$ Azosprillum + PSB) which were statistically significant than all other treatments tried in the experiments.

Maximum sulphur content $(1.38 \%)$ was recorded with $\mathrm{B}_{3}$ (vermicompost $2.5 \mathrm{t} \mathrm{ha}^{-1}+$ FYM $5 \mathrm{t} \mathrm{ha}^{-1}+$ Azosprillum + PSB) which was found at par $1.29 \%$ with treatment $\mathrm{B}_{2}$ (Vermicompost@2.5 t/ha + FYM @ 5 t/ha). These findings are in close agreement with those earlier reported by Sharma et al., (2009) and Mohapatra et al., (2013). 
Table.1 Effect of bio-organics and mineral nutrients on quality and economics of sprouting broccoli

\begin{tabular}{|c|c|c|c|c|c|c|c|c|}
\hline Treatments & $\begin{array}{l}\text { Vitamin-C } \\
\text { (mg/100g) }\end{array}$ & $\begin{array}{c}\text { Crude } \\
\text { protein } \\
\text { content }(\%)\end{array}$ & $\begin{array}{c}\text { Nitrogen } \\
\text { content } \\
(\%)\end{array}$ & $\begin{array}{c}\text { Zinc } \\
\text { content } \\
\text { (ppm) }\end{array}$ & $\begin{array}{c}\text { Sulphur } \\
\text { content } \\
(\%)\end{array}$ & $\begin{array}{c}\text { Boron } \\
\text { Content } \\
(\%)\end{array}$ & $\begin{array}{c}\text { Net return } \\
(\mathbf{R s} / \mathbf{h a})\end{array}$ & $\begin{array}{l}\text { B:C } \\
\text { ratio }\end{array}$ \\
\hline \multicolumn{9}{|l|}{ A. Bio-organics } \\
\hline $\mathrm{B}_{0}:$ Control & 63.46 & 1.67 & 0.267 & 35.13 & 1.10 & 0.0037 & 262023 & 4.54 \\
\hline$B_{1}:$ Vermicompost @ 5 t/ha & 72.84 & 2.01 & 0.322 & 38.54 & 1.22 & 0.0043 & 362089 & 5.34 \\
\hline $\begin{array}{l}\text { B }_{2}: \text { Vermicompost @ } 2.5 \mathrm{t} / \mathrm{ha}+\text { FYM } \\
\text { @ } 5 \mathrm{t} / \mathrm{ha}\end{array}$ & 77.37 & 2.14 & 0.342 & 39.82 & 1.29 & 0.0046 & 391577 & 6.09 \\
\hline $\begin{array}{l}\text { B }_{3} \text { Vermicompost @ } 2.5 \text { t/ha + FYM } \\
\text { @ } 5 \text { t/ha + Azosprillum + PSB }\end{array}$ & 85.17 & 2.30 & 0.368 & 43.03 & 1.38 & 0.0049 & 460241 & 7.14 \\
\hline SEm \pm & 1.80 & 0.05 & 0.008 & 1.07 & $\mathbf{0 . 0 3}$ & 0.0001 & 7494 & $\mathbf{0 . 1 5}$ \\
\hline $\mathrm{CD}(\mathrm{P}=0.05)$ & 5.19 & 0.15 & $\mathbf{0 . 0 2 3}$ & 3.08 & 0.09 & 0.0003 & 21641 & $\mathbf{0 . 4 3}$ \\
\hline \multicolumn{9}{|l|}{ B. Mineral Nutrients } \\
\hline$F_{0}:$ Control & 65.35 & 1.76 & 0.281 & 33.69 & 1.04 & 0.0034 & 252151 & 3.97 \\
\hline $\mathrm{F}_{1}:$ Sulphur @ 40 kg/ha & 72.05 & 1.96 & 0.313 & 37.55 & 1.20 & 0.0042 & 329564 & 5.17 \\
\hline $\begin{array}{l}F_{2}: \text { Sulphur@ } 90 \text { kg/ha + Zinc @ } 5 \\
\text { kg/ha }\end{array}$ & 78.05 & 2.13 & 0.340 & 41.07 & 1.33 & 0.0048 & 422330 & 6.60 \\
\hline $\begin{array}{l}\text { F }_{3}: \text { Sulphur @ } 40 \text { kg/ha + Zinc @ } 5 \\
\text { kg/ha + Boron @ } 1.5 \text { kg/ha }\end{array}$ & 83.40 & 2.28 & 0.364 & 44.21 & 1.43 & 0.0051 & 471885 & 7.37 \\
\hline SEm \pm & 1.80 & 0.05 & 0.008 & 1.07 & 0.03 & 0.0001 & 7494 & 0.15 \\
\hline $\mathrm{CD}(\mathrm{P}=\mathbf{0 . 0 5})$ & 5.19 & 0.15 & 0.023 & 3.08 & 0.09 & 0.0003 & 21641 & 0.43 \\
\hline
\end{tabular}


Table.2 Interactive effect of bio-organics and mineral nutrients on yield attributes and economics in sprouting broccoli

\begin{tabular}{|c|c|c|c|c|c|c|}
\hline Treatments & $\begin{array}{c}\text { Weight of central } \\
\text { head }(\mathrm{kg})\end{array}$ & $\begin{array}{c}\text { Weight of secondary } \\
\text { heads (kg) }\end{array}$ & $\begin{array}{c}\text { Head yield per } \\
\text { plant (kg) }\end{array}$ & $\begin{array}{c}\text { Head yield per } \\
\text { plot }(\mathrm{kg})\end{array}$ & $\begin{array}{c}\text { Head yield per } \\
\text { hectare }(q)\end{array}$ & $\begin{array}{c}\text { Net return per } \\
\text { hectare }(\mathrm{Rs})\end{array}$ \\
\hline $\mathrm{F}_{\mathbf{0}} \mathbf{B}_{0}$ & 0.177 & 0.093 & 0.270 & 4.32 & 133.33 & 209067 \\
\hline $\mathbf{F}_{0} \mathbf{B}_{1}$ & 0.197 & 0.097 & 0.294 & 4.70 & 145.19 & 232732 \\
\hline $\mathbf{F}_{0} \mathbf{B}_{2}$ & 0.235 & 0.120 & 0.355 & 5.68 & 175.31 & 292799 \\
\hline $\mathbf{F}_{\mathbf{0}} \mathbf{B}_{3}$ & 0.249 & 0.127 & 0.376 & 6.02 & 185.68 & 313492 \\
\hline $\mathbf{F}_{1} \mathbf{B}_{0}$ & 0.209 & 0.109 & 0.318 & 5.09 & 157.04 & 246467 \\
\hline $\mathbf{F}_{1} \mathbf{B}_{1}$ & 0.259 & 0.137 & 0.396 & 6.34 & 195.59 & 323542 \\
\hline $\mathbf{F}_{1} \mathbf{B}_{2}$ & 0.315 & 0.174 & 0.489 & 7.82 & 241.33 & 414847 \\
\hline $\mathbf{F}_{1} \mathbf{B}_{3}$ & 0.346 & 0.192 & 0.538 & 8.61 & 265.68 & 463492 \\
\hline $\mathbf{F}_{2} \mathbf{B}_{0}$ & 0.219 & 0.116 & 0.335 & 5.36 & 165.43 & 266764 \\
\hline $\mathbf{F}_{2} \mathbf{B}_{1}$ & 0.273 & 0.147 & 0.421 & 6.73 & 207.71 & 351278 \\
\hline $\mathbf{F}_{2} \mathbf{B}_{2}$ & 0.333 & 0.186 & 0.518 & 8.29 & 256.00 & 447692 \\
\hline $\mathbf{F}_{2} \mathbf{B}_{3}$ & 0.366 & 0.206 & 0.572 & 9.15 & 282.47 & 500572 \\
\hline $\mathbf{F}_{3} \mathbf{B}_{0}$ & 0.234 & 0.121 & 0.355 & 5.68 & 175.31 & 286297 \\
\hline $\mathbf{F}_{3} \mathbf{B}_{1}$ & 0.319 & 0.162 & 0.481 & 7.70 & 237.53 & 410704 \\
\hline $\mathbf{F}_{3} \mathbf{B}_{2}$ & 0.397 & 0.209 & 0.606 & 9.70 & 299.26 & 533981 \\
\hline $\mathbf{F}_{\mathbf{3}} \mathbf{B}_{\mathbf{3}}$ & 0.448 & 0.235 & 0.683 & 10.93 & 337.28 & 609982 \\
\hline SEm \pm & 0.017 & 0.009 & 0.026 & 0.40 & 10.54 & 14988 \\
\hline $\mathrm{CD}(\mathrm{P}=\mathbf{0 . 0 5})$ & 0.048 & 0.025 & 0.076 & 1.16 & 30.42 & 43282 \\
\hline
\end{tabular}




\section{Effect of mineral nutrients}

The results (Table 1) indicates that the maximum crude protein content $(2.28 \%)$ in head was recorded with treatment $\mathrm{F}_{3}$ (S @ 40 $\mathrm{kg} \mathrm{ha}^{-1}+\mathrm{Zn} @ 5 \mathrm{~kg} \mathrm{ha}^{-1}+$ Boron@1.5 kg $\mathrm{ha}^{-1}$ ) found at par $2.13 \%$ with treatment $\mathrm{F}_{2}$ (Sulphur@40kg/ha+Zinc@5 kg/ha). Maximum vitamin-c content $(83.40$ $\mathrm{mg} / 100 \mathrm{~g})$, nitrogen content $(0.364 \%)$, zinc content (44.21 ppm), sulphur content $(1.43 \%)$ and boron content $(0.0051 \%)$ in head were recorded with treatment $\mathrm{F}_{3}\left(\mathrm{~S} @ 40 \mathrm{~kg} \mathrm{ha}^{-1}+\right.$ Zn@5 kg ha ${ }^{-1}+$ Boron@1.5 kg ha ${ }^{-1}$ ). The increase in protein content with the application of $\mathrm{S}, \mathrm{Zn}$ and $\mathrm{B}$ might be due to sufficient nitrogen uptake by the plant which was facilitated by the applied these nutrients because sulphur is a constituent of S-bearing amino acids and helps in stabilizing protein structure. Boron is essential for protein synthesis and zinc boost protein synthesis by improving RNA formation (Havlin et al., 2009). Similar findings were recorded by Hunashikatti et al., (2000) in cabbage and Jamre et al., (2010) in cauliflower.

\section{Interaction effect}

A perusal of data in table 2 revealed that the interaction effect of bio-organics and mineral nutrients was found significant in sproutiong broccoli. The application of vermicompost @ $2.5 \mathrm{t} \mathrm{ha}^{-1}+$ FYM @ $5 \mathrm{t} \mathrm{ha}^{-1}+$ inoculation of seedlings with Azosprillium + PSB culture along with S@40 kg ha ${ }^{-1}+\mathrm{Zn} @ 5 \mathrm{~kg} \mathrm{ha}^{-1}+$ Boron@1.5 kg ha ${ }^{-1}$ significantly enhanced yield characters. The maximum weight of central head $(0.448 \mathrm{~kg})$ and weight of secondary heads $(0.235 \mathrm{~kg})$ were recorded with $\mathrm{F}_{3} \mathrm{~B}_{3}$ treatment combination. The increase in weight of central head and secondary heads might be due to the possible role of organic, inorganic fertilizers and Azosprillium through atmospheric nitrogen fixation, increased availability of phosphorus through PSB, better root proliferation, uptake of nutrients and water, higher photosynthetic activity and enhanced food accumulation which might have resulted in better plant growth and subsequently higher yield. Similar effects were reported by Maurya et al., (2008) in broccoli and Shree et al., (2014) in cauliflower.

Total head yield $\left(0.683 \mathrm{~kg}\right.$ plant $^{-1}, 10.93 \mathrm{~kg}$ plot $^{-1}$ and $337.28 \mathrm{q} \mathrm{ha}^{-1}$ ) were exhibited maximum with application of vermicompost @ $2.5 \mathrm{t} \mathrm{ha}^{-1}+\mathrm{FYM} @ 5 \mathrm{t} \mathrm{ha}^{-1}+$ inoculation of seedlings with Azosprillium + PSB culture along with S@40 kg ha ${ }^{-1}+\mathrm{Zn} @ 5 \mathrm{~kg} \mathrm{ha}^{-1}+$ Boron@1.5 kg ha ${ }^{-1}$. Such increase in yield has been reported to be associated with the release of macro and micro nutrients during course of microbial decompositions. Organic matter also functions as source of energy for soil micro flora which brings about the transportation of inorganic nutrients held in soil or applied in the form of fertilizer in a farm that is readily utilized by growing plant. The beneficial effects of FYM and vermicompost addition are also related to improvement in soil physical properties. Besides this the beneficial response of organic manures to yield might also be attributed to the availability of sufficient amounts of plant nutrients throughout the growth period and especially at critical growth period of crop, resulting in better uptake, plant vigour and superior yield attributes. The similar findings have also been reported by Manivannan and Singh (2004) in Broccoli, and Wani et al., (2011) in Cauliflower.

\section{Economics of the treatment}

The economics of different treatments viz., net return and benefit cost ratio has been worked out and presented in table 1. Data presented in the table showed that treatment $\mathrm{B}_{3}$ (vermicompost $2.5 \mathrm{tha}^{-1}+5 \mathrm{tha}^{-1} \mathrm{FYM}+$ Azosprillium + PSB) and $\mathrm{F}_{3}$ (S @ $40 \mathrm{~kg} \mathrm{ha}^{-1}+$ 
Zn@ $5 \mathrm{~kg} \mathrm{ha}^{-1}+$ Boron @ $1.5 \mathrm{~kg} \mathrm{ha}^{-1}$ ) found maximum in terms of net returns (Rs. 460241 and Rs. 471885) and B:C ratio (7.14:1 and 7.37:1) respectively. Net return was influenced significantly by interactive effects of bio-organics and mineral nutrients. The interaction of treatment $\mathrm{F}_{3} \mathrm{~B}_{3}$ (Rs $609982 \mathrm{ha}^{-1}$ ) showed maximum net return (Table 2). These results are found similar to USDA Economics, Statistics and Market Information System.

In conclusion, study revealed that the integration of bio-organics and mineral nutrients had shown a marked effect in enhancing yield as well as productivity of broccoli with maximum net returns. On the basis of results, it could be concluded that the application of vermicompost @ $2.5 \mathrm{t} \mathrm{ha}^{-1}+$ FYM@ $5 \mathrm{t} \mathrm{ha}^{-1}+$ Azosprillium + PSB along with S@40 kg ha ${ }^{-1}+\mathrm{Zn} @ 5$ kg ha ${ }^{-1}+$ Boron@1.5 kg ha ${ }^{-1}$ were best for higher yield with maximum profit and can be recommended for commercial production of broccoli.

\section{References}

Bahadur, A., Singh, J., Upadhyay, A. K. and Singh, K. P. 2003. Effect of organic manures and biofertilizers on growth, yield and quality attributes of broccoli (Brassica oleracea var. italica plenck) Veg. Sci. 30(2): 192-194.

Choudhary, S., Soni, A.K. and Jat, N.K. 2012. Effect of organic and inorganic sources of nutrients on growth, yield and quality of sprouting broccoli cv. CBH-1. Indian Journal of Horticulture, 69(4): 550-554.

Havlin, J.L. 2009. Soil fertility and fertilizers - an introduction to nutrient management. PHI Learning Private Limited, New Delhi.

Hunashikatti, M.G., Channel, H.T., Sarangamath, P.A., Manjenathaian, M.M. and Dharamatli, P.R. 2000. Effect of $\mathrm{S}$ and Mo on the dry matter yield and quality of cabbage (Brassica oleracea var. capitata). Fertilizer News, 5(8): 8385.

Jamre, B.R., Nagaich, K.N. and Verma, H. 2010. Effect of different levels of $S$ and $\mathrm{Zn}$ on growth and yield of cauliflower (Brassica oleracea var. botrytis). Asian Journal of Horticulture, 5(2): 323-325.

Kumar, A., Parmar, D.K. and Suri, V.K., 2012. Effect of boron fertilizers and organic manure on autumn cauliflower in Western Himalayas. Annals of Horticulture, 5(1): 17-24.

Manivannan, M. I. and Singh, J. P. 2004. Effect of biofertilizers on the growth and yield of sprouting broccoli (Brassica oleracea var. italic Pelnck) under Allahabad Agro-Climatic conditions. Bioved. 15(1/2): 33-36.

Maurya, A.K., Singh, M.P., Srivastava, B.K., Singh, Y.V., Singh, D.K. and Singh, P.K. 2008. Effect of organic manures and inorganic fertilizers on growth characters, yield and economics of sprouting broccoli cv. Fiesta. Indian Journal of Horticulture, 65(1): 116-118.

Mishra, P.P., Das, A.K. and Mishra, N. 2014. Effect of integrated nutrient management on yield, quality and economics of knolkhol (Brassica oleracea L. cv. gongylodes). Asian J. Horticulture, 9(2): 382-385.

Mohapatra,S.K., Munsi, P.S. and Mohapatra, P.N. 2013. Effect of Integrated Nutrient Management on growth, yield and economics of broccoli (Brassica oleracea L. Var. italic plenck). Vegetable Science, 40(1): 69-72.

Sable, P. B. and Bhamare, V. K. 2007. Effect of bio-fertilizers (Azotobacter and Azospirillum) alone and in combination with reduced levels of nitrogen on quality of cauliflower cv. Snowball-16. The Asian J. Hort. 2(1): 215-217.

Sharma, R.P., Dutt, N. and Chander, G. 2009. 
Effect of vermicompost, farm yard manure and chemical fertilizers on yield, nutrient uptake and soil fertility in okra (Abelmoschus esculentus), onion (Allium cepa) sequence in wet temperature zone of Himachal Pradesh. Journal of the Indian Society of Soil Science, 57: 3.

Shiwani, Kumari, Katoch, Viveka, Sharma, Akhilesh and Kumara, Vedna 2016. Variability studies in sprouting broccoli hybrids (Brassica oleracea L. var. italic Plenck) under mid hills of north western Himalayas. The Bioscan. 11(1): 569572.

Shree, S., Singh, V.K., and Kumar, R. 2014. Effect of integrated nutrient management on yield and quality of cauliflower (Brassica oleracea var. botrytis L.). The Bioscan, 9(3): 10531058.

Talashilkar, S.C., Bhangarath, P.P. and
Mehta, V.B. 1999. Changes in chemical properties during composting of organic residues as influenced by earthworm activity. Journal Indian Soc. Soil Science, 47 (1): 50-53.

Thamburaj, S. and Singh, Narendra 2013. Textbook of Vegetables, Tuber crops and Spices. Indian Council of Agricultural Research, New Delhi (India). p. 136.

Wani, A.J., Raj Narayan, Ahmed, N., Singh, A.K., Chattoo, M.A., and Narayan, S. 2011. Influence of organic and inorganic sources of nutrients on growth, yield and quality of cauliflower (Brassica oleracea var botrytis L.). Environ. Ecol., 29(4): 1941-1947.

Yoldas, F., Ceylan, S., Yagmur, B. and Mordogan, N. 2008. Effects of nitrogen fertilizer on yield quality and nutrient content in broccoli. J. Plant Nutri, 31(7): 1333-1343.

\section{How to cite this article:}

Sunil Choudhary and Ravinder Paliwal. 2017. Effect of Bio-Organics and Mineral Nutrients on Yield, Quality and Economics of Sprouting Broccoli (Brassica oleracea var. italica). Int.J.Curr.Microbiol.App.Sci. 6(12): 742-749. doi: https://doi.org/10.20546/ijcmas.2017.612.078 